\title{
Indigenous Indonesian Dayak Traditional Wisdom in Reducing Deforestation
}

\author{
Sidik R. Usop ${ }^{1^{*}}$ and Ismi Rajiani ${ }^{2}$ \\ ${ }^{1}$ Faculty of Social Sciences, Universitas Palangkaraya, Indonesia, ${ }^{2}$ Faculty of Economics \& Business, \\ Universitas Lambung Mangkurat, Indonesia
}

Received: $2019-05-18$ Accepted: 2021-07-10

Keywords:

Dayak; forest;

local wisdom;

sustainability;

sacred area.

Correspondent email: srusop@yahoo.co.id

\begin{abstract}
The function of forests for Dayak people is not only to fulfill the needs of life but also related to the ancient belief to preserve natural resources. The study aims to analyze the traditional model of protecting the conservation area by applying surveys and in-depth interviews. In this particular case study, a set of values batang garing (tree of life), belom bahadat (living compliant with customary law), pali (taboo), manyanggar (asking the consent of the ancestor),memapas lewu (brushing the village) - central to the Dayak Ngaju people, the indigenous population in Central Kalimantan, become contested in the course of the economic and development project. Adherence to these central values creates movement to prevent damage to indigenous people's natural resources under the tag "Manyalamat Petak Danum" (Saving our TO "Manyalamat Petak Danum" (Saving our Homeland)
\end{abstract}

@2021 by the authors. Licensee Indonesian Journal of Geography, Indonesia.

This article is an open access article distributed under the terms and conditions of the Creative Common Attribution(CC BY NC) licensehttps://creativecommons.org/licenses/by-nc/4.0/.

\section{Introduction}

Sustainability, understood as everything related to preserving resources for future generations, is one of current society's significant concerns worldwide, making the issues are debated in summits and conferences to find the best ways to alleviate the current situation (Araújo et al. 2018).

In Indonesia, the sustainability trends enter rural regions due to the country's commitment to The United Nations Framework Convention on Climate Change (UNFCCC), which is to be achieved through several mitigations including sustainable peatland management; reducing the rate of deforestation and land degradation; and developing carbon sequestration projects in forestry and agriculture (Rajiani \& Kot, 2018). In Kalimantan, one of the biggest Islands, the amount of wilderness is $126,200 \mathrm{~km}^{2}$ that must be preserved and conserved to reduce carbon emissions and global warming. Likewise, the availability of peatland is 3,010,640 ha or $52.18 \%$ of the total peatland in Kalimantan, attracting the world's attention to Indonesia's importance to save the earth due to climate change. Uniquely, within the forest area, there are sacred forest areas called pahewan (Lounela, 2020). Currently, the existence of pahewan is threatened by plantation, mining and forest concession investments. This because, alike elsewhere in Southeast Asia, economic strategies and land utilization model of forest interface in Kalimantan have intensively increased as the result of interactions with international markets accompanied with a dual economy track at a regional level in providing for local needs as well as generating income for local government (Silvianingsih et al.,2020).

Consequently, most forest areas are divided by road networks, access routes, and various development activities like plantations and industrial infrastructures. Besides exploitation from timber companies and mining concession, some areas are used for smallholder agriculture by the indigenous Dayak people who inhabit the area. The ground continues to burn frequently, leading to trans boundary haze with similar spatial configuration of deforestation (Arjasakusuma et al., 2018), making this region the highest contributor of greenhouse gas emissions (Wegscheider et al., 2018; Arisanty et al.,2020).

Due to the importance of the Borneo forest for the world, there has been pressure to restore, rehabilitate, and develop this region globally significant for carbon emissions reduction, development, and biodiversity (Law et al., 2015; Savage, 2018). Since the failure of forest governance systems in Central Kalimantan was due to land conflicts primarily between local communities and government, followed by communities and companies, and communities against communities (Meyer et al.,2018), it is necessary to develop potential future land-use scenarios for the region by applying the local wisdom to avoid further conflict with local people. Local wisdom - the ancestors' heritage in the repertoire of the values of life united in the form of beliefs, culture, and customs (Yang et al., 2019) - recently is applied in managing the environment in Indonesia. Each region applies a specific concept of local wisdom like Tri Hita Karana (the three causes of well-being) in Bali (Sukawati et al.,2020); Pranotomongso (calculation based on Javanese calendar to determines planting time ) in Java (Zaki et al., 2020); Bondang (ceremony in opening and closing land) in Sumatra (Ma'ruf, 2018); Pasang ri Kajang (messages from/in Kajang) encompasses the collection of messages, advice, 
instructions procedures for establishing and maintaining harmonious relationships with nature, humans, and God in Sulawesi (Osman et al.,2020). Further, local wisdom for regional development has been applied in developed countries of the eastern hemisphere like Japan (Fukamachi, 2017) and Australia (Brown, 2015). However, these studies are in agriculture where the forest has undergone land clearance, so it remains unclear if the concept applies to a virgin forest.

Over the past three decades, management teams, particularly those charged with the administration of protected areas, have become increasingly interested in developing institutional arrangements that provide opportunities to promote a role for local people involved in natural resource management decision making (Ross et al., 2016). This is because local communities are much more motivated to preserve the forests than outsiders tending to possess vested interests (Cheung et al.,2018; Gupta \& Koontz, 2019; Takala et al.,2020).

Therefore, this study focused on exploring and understanding the cultural values, particularly the traditional knowledge related to the conservation of forest resources among Dayak people in Central Kalimantan. In this region, indigenous people living on the outskirts of the forest and in the forest constantly preserve the forest for the community's survival. Maintaining customary forests shows their concern for conservation and defending customary, inherited, and traditional rights passed down from generation to generation (Njau et al., 2019).

\section{Methods}

Data collection was undertaken from 2017 to 2018, then completed in 2020.

Under the public authority, various gatherings of transients supported immigration program just as unconstrained travelers have also dwelled the region, coming from Bali, Java, Flores, and elsewhere else. Only people that portrayed themselves as Dayak Ngaju ethnic birthplace were considered in this examination, as we needed to record nearby natural information with authentic roots in this scene. A huge territory of wetlands is situated in the Gunung Mas Regency, where the examination was directed. The financial wheel in Gunung Mas Regency relies upon the rural area while the accessibility of agricultural land territory is restricted; along these lines, the potential for transformation of woodland land remains a key interest. The distribution of where Central Kalimantan' Dayak ethnics reside is depicted in Figure 1. The green color region is the territory of Dayak Ngaju ethnics where the study was conducted.

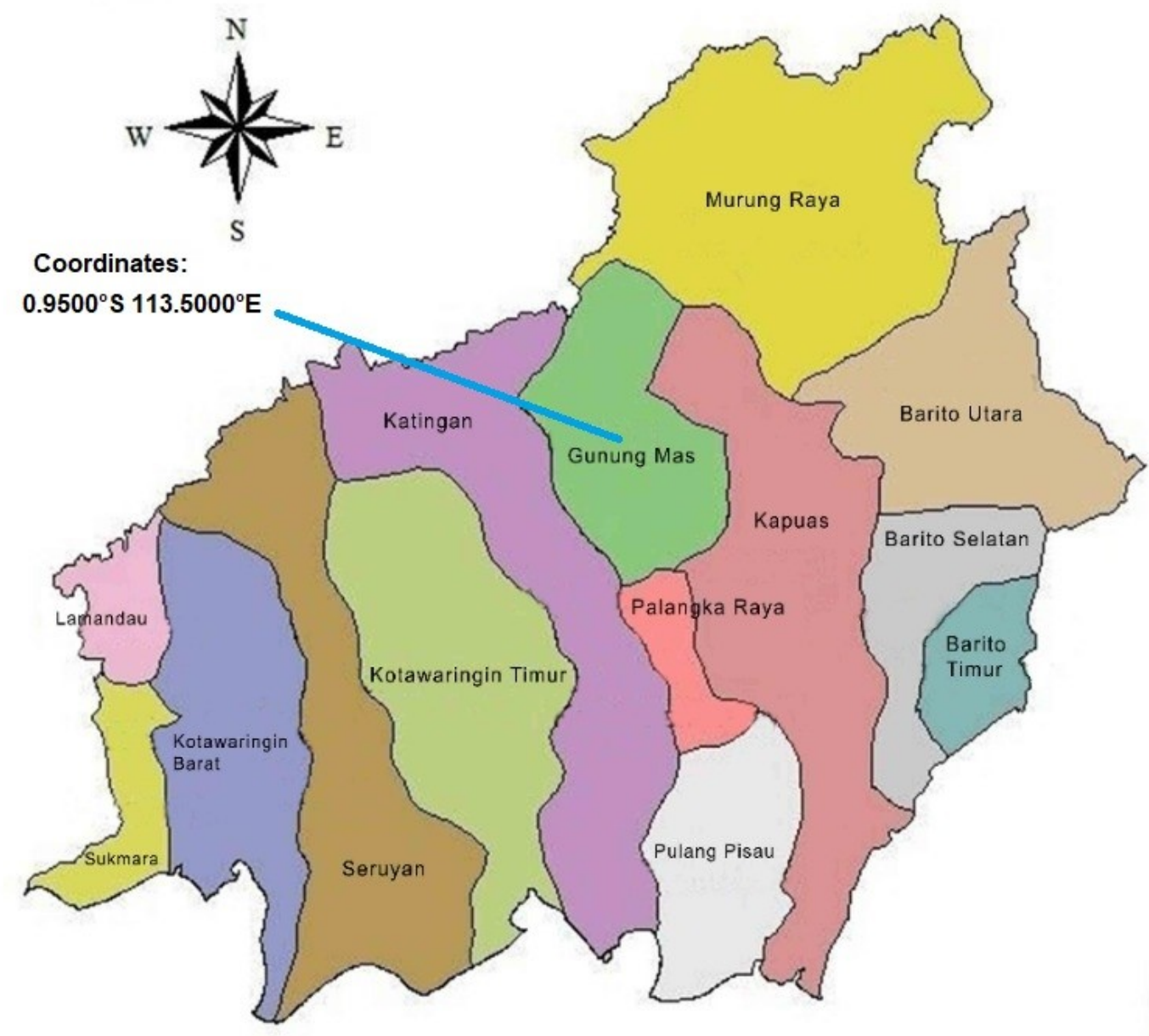


Consent for research was acquired from the village elders, and the first author, with more than five years' involvement with the territory was invited in the homes of numerous villagers, with subsequent meetings in the field, and participation in village ritual events. Information assortment was carried out by field observations, and indepth interviews with 6 key informants (purposive sampling) consisting of three damang kepala adat (resident adat practitioners). The government officially appoints the damangs in Central Kalimantan based on merit for sound knowledge and customary law expertise. Another three key sources were land-proprietors with profound information on the land history from backwoods land clearing stage to land development, known about different kinds of neighborhood restrictions/or have been overseeing land in these villages. The respondents are marked as D1, D2, D3, L1, L2, and L3. Inside and out meetings were led in the Dayak Ngaju language and Bahasa Indonesia. The meetings were recorded, completely translated and deciphered into Bahasa Indonesia. Where meetings seemed to give clashing data, joint field visits were made to guarantee data was accurately deciphered and was identified with field information. A thematic approach (Fei, 2019) to association and translation of information was utilized in which the information was cut and masterminded under important units of understanding.

\section{Result and Discussion}

\section{Dayak's Traditional Belief Toward Forest Preservation}

Indigenous Dayak tribes, as in other Southeast Asian countries, develop agricultural systems adapted from the tropical forest ecosystem. It is governed by customary law, i.e., regulations made and enforced according to indigenous peoples' consensus. Dayak indigenous institutions play an essential role in managing ecosystems. The Dayak vision of prosperity suggests that rivers, soils, and forests are necessary for ethnic identity. The same concept is shown in the mosaic patterned of shifting cultivation system in the woods they live. In shifting cultivation, mosaics patterns consist of collecting natural forest, artificial forests, vacant land, and fields by ecological conditions and local topography (Widen, 2017). Generally, original Dayaks are genuine conservationists; they build a strategy for biodiversity and environment conservation to sustain sustainable living needs. Since thousands of years ago, the Dayak people of Borneo use traditional knowledge of shifting cultivation to manage natural resources and biodiversity in the forest. They build and use specific steps as a strategy for the conservation of natural resources and the environment. At first, they learn the limitations of natural resources, where the excessive and unwise use of them will reduce availability and sustainability. Traditional knowledge is the unique local knowledge owned by a particular culture or society. This knowledge is the accumulation of human knowledge and understanding of the universe, including the spiritual relationship with the Almighty, the relationship with nature, and relationship with humans, and it is reflected in language, organization, values and law system, to be the ethics that govern the behavior of a society. Dayak tribe usually believes that there is a limitation of natural resources; thus it requires conservation, except for certain types of resource availability which exceeds demand (Pirard et al. 2016).

The cultural values of the Dayak people, Central Kalimantan, are based on Kaharingan Hinduism beliefs. The name Kaharingan comes from the word "Haring", which means "by itself." In essence, the Kaharingan belief considers that all objects and creatures have the gana (spirit), and there is only one God called Ranying Hatala Langit that creates all the contents of the universe. The origin of human creation and universe are described by symbol of Batang Garing (tree of life) in which there is hornbill as a symbol of upper world's ruler and dragon for the underworld. Today, the Batang Garing symbol is understood by the Dayak community as a balance of human relations with nature and the balance of relationships between humans.

In everyday life, Kaharingan people believe in divine power whose duty is to help human safety, provide sustenance and spread disease, etc. that are spread in the water (rivers, lakes, and seas), mountains, forests, plants, and specific places. For Kaharingan adherents, divine beings are very influential in determining every aspect of human life. Luck and misfortune of life, natural disasters, and accidents occur because of people actions. Therefore, the highest form in Kaharingan's belief practice is obeying adat (local customary), namely not breaking pali (taboo) and carrying out ritual ceremonies called gawi belom (ceremonies of life), mamapas lewu (cleaning the village), manajah antang (calling the eagle) and gawi matei (death ceremony).

D1 damang kepala adat in Rakumpit sub-district said:

"We understand that the pahewan in this area is sacred forests due to the existence of big trees and the gana (spirits). Therefore, when people want to open a new land, they must ask permission from the spirit that inhabits the forest area by conducting a manyanggar (asking permission) ceremony. According to our belief, if the group does not do it, our village will get a disaster."

D1 said specifically:

Violation of taboo is considered as uncivilized and impolite manner so that it can disrupt life in the future.

Based on the community's traditional knowledge, the Pahewan Tabelien forest area can still be preserved to this day. L1 community members in Mungku Baru Village reported:

"In 2008, one resident took wood from the sacred area to build a house. A few days after taking the wood, he experienced illness and died. In the community's view, being sick and even dying is the result of violating pali (taboos) against the pahewan area which is considered sacred by the community".

Also, L1 said:

"After the incident, the village's people always talked about the incident that happened to the poor guy due to taking wood in the forest. It turned out that with this incident, people were afraid to violate the taboo in the area of the pahewan ". We held the traditional ceremony of manyanggar (asking permission) so that our village would not experience mayhem due to the operationalization of a timber company that exploited the pahewan area. One year, we also held a traditional ceremony memapas lewu (cleaning the village) to remind the public that the incident will not recur".

By adopting the framework of Großmann (2017), the Dayak's community living in Central Kalimantan is 
categorized into four communities: primordial Dayak, traditional Dayak or adat community, outskirt Dayak, and rational Dayak. Community $1-$ a primordial culture community is an isolated tribe that lives in a physically secluded area and is also culturally separated from the outside world. The magical force guides their entire conduct with specific patterns: their economic system is based on woods product collecting or wild animal hunting. They assume that all the lands utilized for the living are common property and shared about land utilization as their livelihood. Their way of life is laid on the guide of their ancestors' spirits; in other words, social control towards the behavior of members of society is watched by the spirits. The acknowledged guidance of the spirits is transmitted through natural phenomenon and via the medium of tribes' chief. This type of society still can be found in the hinterland of Borneo. The next, Community 2 - is a culturally more developed society as its culture has moved forward to the stage of traditional culture or adat society. Although they still believe in the spirits of their ancestors in this level of community, they have molded their confidence so that they can interact with neighboring villages around the tribe. Besides, they can create a customary law - adat law as their foundation of life. In other words, the socio-cultural institutions which serve as the instruction for social interactions in the social structure and operation are limited by the custom getting stronger and stronger over time, so that it grows into adat law. As a social control utility, the adat law norm has a vital role in keeping the peace, safety, and prosperity; monitored by members of the society not by the spirits as in group 1). Each of the institutions created by and for the benefit of society based on the adat law is regarded as the moral and legal source.

The following third group is the society that dwells in villages near the cities. Although the state law already governs their way of life, adat law is still present in specific aspects in the relationship among society members. The members of this society have made a living through various professions, but farming is still the primary model of their economy; hence, the land holds an essential role in the economic aspect. Thus, besides the center of farming activities, the land could become the most precious investment asset. Finally, the last group is the society that has developed into the rational culture stage by following the modern way of life, where rationality is the primary reason to lead a convenient and prosperous life. This way, their life order is governed by the rational-legal norms derived from the state law, including land use. The land is an asset to invest in the economic motive. As urban populations, they usually possess formal education and live there with the investors' mind attempting to enlarge the investment to villages or adat law society areas when an opportunity is seen. They conduct the land business under state law provisions about the business location permit and land rights policy in which adat law society exists.

Nevertheless, the threat to preserving the pahewan inevitably comes from outside like timber and palm oil companies as a land clearing in the rural area usually creates various land conflicts that ends with land disputes between inhabitants. Conflicts that typically happen are associated with the management of communal land rights within the context of the adat law community that has then turned to land utilizations occupied by the third party (investors). As such, to accommodate both interests, D2, one of indigenous community chief or locally known as damang kepala adat explained that the thoughts in the meeting of the Central Kalimantan Chief of Damang:

"First, the wise utilization and management of natural resources to the environment are to ensure the continuity of human life in the future. Second, the use of natural resources must be for the welfare of the community; third, belom bahadat (living compliant with customary law) serves as guidance in regulating human relationship with nature to encourage local wisdom in managing and utilizing natural resources in the life together, and in the utilization of public space that preserved harmony atmosphere. Fourth, the customary law institution called Kademangan must be strengthened and to optimize the role of Damang in resolving problems that occur in the community. Fifth, opening the isolation of the Dayak population in the hinterland reduces inequality in the communities living in the estuary of rivers or cities.

The government's support is the issuance of Central Kalimantan Provincial Regulation No. 16 of 2008 stated that the decision of adat proceeding should be final and binding on the parties to the dispute implying an obligation for outsiders to comply.

\section{Community Values Conflict in Forest Utilization}

Up to this point, the land conflict settlement model frequently does not come up with expected results satisfying both parties. Even after the verdict has been determined by the court, it seldom brings peace among the contesting parties. The adat law community usually becomes the losing party in these disputes. On the other hand, the businessmen also must pay for the compensation multiple times as investors could not meet all the compensation demands filed by the adat law community. Meanwhile, the said dispute settlement mechanism has yet to be regulated by the government; this causes the inability of land conflict cases to be settled effectively and efficiently. Because of that, the land conflict situation in Indonesia has become wider (Lestarini, 2016).

In the life of the Dayak people, forests are not only to fulfill economic needs, but also to fulfill ritual functions and society's survival in the future. The disruption of the forest's role in the lives of these people will encourage the emergence of social conflicts such as those that occur between the community and businesspeople holding concessions and planters. L2, the landowner who is also the Hindu Kaharingan religious figure said:

Concerning the use and management of natural resources, several customary activities must be carried out so that their efforts do not get disturbed by spirits who inhabit the natural environment around. One of the traditional activities is spreading the yellow rice conveyed to the inhabitants' souls in the river, in the forest and in places that are considered sacred by the local community.

In response to the effects of global warming and climate change, Indonesia including the Central Kalimantan has been labelled as a pilot of the Reduce Emission from Deforestation and Degradation (REDD + conservation) project since 2010 
(Rajiani \& Pypłacz, 2018). Long before this policy of the incentives-based mechanism aimed at rewarding the governments of developing countries to lessen deforestation as measured against a standard, the people have preserved the forest in their traditional way. L3, the local people who is also academia confirmed:

"Ulin wood (eusideraxylon zwageri) has become a part of community life (socio-ecological) because it was inherited from the previous generation in a form that is still preserved. Therefore, the village community must maintain awareness to prevent it (mitigation) from damage that can cause disasters to human life.

Understanding at the indigenous community level regarding the management of the indigenous conservation area called pahewan is that it is considered a sacred forest area that should not be disturbed. Disruption of pahewan is considered breaking the taboo that can cause disaster to people who have harassed the area. It frequently happens that villagers who looted wood in the pahewan suffered severe pain. The incident is continuously conveyed repeatedly to other residents, causing residents' fears to disrupt the pahewan area. Thus, to avoid the event, D3, the traditional community head (damang) said:

"If we want to use the forest for the benefit of the community, then the ceremony must be carried out beforehand. The ceremony according to Damang is to request permission from the ancestral spirit before clearing land or utilizing wood in the pahewan. If the ceremony is not carried out, then their village will experience a disaster. Besides, the cleaning village ceremony is held every year so that their villages are protected from natural disasters and epidemics as well as the disorders of evil spirits."

The people, especially the adat law society, accept the government's economic development. From them, the most important thing is the actual function of the growth that could serve the community's livelihood. The event is perceived with hesitance, especially if the development alters or causes deviation from the adat law that exists in the concerned adat law society. The difference from the adat law is perceived as a violation of adat norms and regarded as a violation of their religious rules, and therefore, interferes with their harmony of life that is respected by society. Consequently, the development interferes because adat law deviation causes conflict between communities that firmly adheres to the adat law and formalistic rules. The impact is, of course, it creates uncertainty of land rights which both parties probably perceive. If it is not resolved then it could cause an open conflict. An open conflict would arise when unrest is felt widespread but latent in the own adat law society. This sense appears because of the social injustice perceived by communities that are caused by government policies towards the community or the domination of a faction in society towards the adat law society. This sense of unrest in the adat law society leads to a tense atmosphere, with the pressures that get higher over time until the conflict is unstoppable.

Up to this point, the government has had no regulations on the dispute settlement between the adat law society and the investors related to the utilization and ownership of natural resources (land). Currently, existing regulations are guidelines to address the settlement of issues of the adat law society in the perspective framework of conflict prevention with external parties or investors through recognition from the state.

From an early age, public awareness has been very high to secure the forest as part of their lives bound by tradition and traditional belief. The coming of the timber industry, the changes of the population both regarding numbers and the religious diversity, further strengthened public awareness to maintain pahewan as a region that is protected by custom. Those external factors lead to the construction of knowledge of the community groups to support the preservation of natural resources. This way, the community uses the ancestral spirits as watchmen staying in the woods by chanting the verses: ingat peteh tatu hiang, petak danum akan anak esu harian andau (remember the old messages, natural resources are for future generations).

External and internal influences that occur in the dynamics of people's lives have presented the construction of traditional ritual understandings called menyanggar (asking for ancestral consent) as a form of caution in gaining and using natural resources so that people do not arbitrarily treat natural resources that are not only intended for today's life but also for the lives of future generations. The construction of this understanding is also reinforced by traditional ceremonies memapas lewu (brushing the village) conducted once a year, which serves as an effort to build human awareness to preserve natural resources for human survival and prevent natural disasters.

In the dynamics of managing the pahewan, the community must obey the principle of belom bahadat (living compliant with customary law) inherent in every social interaction, both in the interaction between man and fellow human beings, as well as human interaction with the natural environment which is bound by the traditional legal, customary norms.

As a driving force and controlling the dynamics of human life, both in their interactions with fellow human beings and their interactions with the natural environment, the people must obey Ranying Hatala Langit as the ruler of the upper layers of the world as well as the ruler of the underworld presented through the symbol Batang Garing to remind humans in order to always maintain the harmony of relations between humans and nature as a manifestation / reflection of the belief in God Almighty.

The occurrence of pahewan as a protected area is through a formation process that involves the community and community informal leaders in responding to the problems. The integration between the knowledge and the life experience they have experienced has formed a shared understanding and shared awareness to defend or resist the external influences they are facing. Therefore, the actions taken will always be related to the cultural values and knowledge possessed by the group or community concerned. To sum, the cultural activities performed in molding the community's values are presented in Table 1.

The cultural values in points 1 to 5 are cultural identities used to strengthen the belief that the pahewan area is an area that must be protected based on the customs of Dayak people in Central Kalimantan. Additionally, points 6 and 7 emerge from thematic approach to construct the traditional 
knowledge that strengthens efforts to pahewan as a sacred forest area protected by custom. The construction of knowledge driven by the community and community leaders is a process of interaction and integration of traditional culture that is mutually reinforcing in response to the dynamics of people's lives as well as outside influences that are considered to disturb the sustainability of natural resources in the indigenous conservation areas.

The model of local wisdom in preserving the forest for sustainability is summarized in Figure 1. Community dynamics in the management of customary conservation areas is highly dependent on local community leaders who creatively construct pahewan with understanding as sacred forests that should not be disturbed because magical spirits are waiting for the woods, so disruption to the forest is considered to be a violation of the pali (taboo) which can cause death and misery of the person who violates it. An understanding of this cultural aspect shows that the community has a strong desire to maintain the local culture as an identity that cannot be separated in society's development. In other words, there is a process of knowledge construction that integrates development values with traditional values being combined in people's lives. From the environmental aspect, pahewan is understood as a buffer zone because only the pahewan which was able to survive forest fires in the long dry season in 1991 and 2001. With this understanding, the pahewan must be protected and maintained for continuity live the people around the forest as stipulated in local people's adage: "remember ancestral messages, land, water and natural resources for the survival of future generations."

The context of understanding is very relevant to the concept of sustainability in natural resource management. Survival is not only for human needs but also for the survival of various biological resources, including plants and animals, including microorganisms needed in maintaining ecosystems. Besides, pahewan is also regarded by the community as financial assets that will contribute to the welfare of the community. One of the community businesses that depend on forest and the water system's continuity is a fishing business in the river. Thus, the pahewan area is a vital natural resource that must be conserved to ensure the community's sustainability of small business.

The management of indigenous conservation areas by local communities has undergone construction of understanding in response to external influences that can threaten natural resources' sustainability. The perception that occurs is streamlining local cultural values to strengthen the efforts to preserve the customary conservation area. Thus, In the Dayak people community, the environmental sustainability model has been developed long ago as part of the ecosystem that affects the conservation area management system. Sadly, the investors pursuing the business profit ignore the local wisdom, making the gap with the local people wider.

Walker (2016) recorded the socio-economic development that did not practice the traditional custom. The loss of indigenous knowledge causes the rapid degradation of the

Table 1. Value of Communities in the Sacred Area

\begin{tabular}{lll}
\hline No. & Values & Meaning \\
\hline 1. & Batang Garing & $\begin{array}{l}\text { Symbols describe the balance of human } \\
\text { and human relations; social relations with } \\
\text { nature; and human relations with the crea- } \\
\text { tor. }\end{array}$ \\
2. & $\begin{array}{l}\text { Belom Bahadat (living } \\
\text { compliant with customary }\end{array}$ & $\begin{array}{l}\text { An embodiment of the Batang Garing } \\
\text { symbol is derived in the form of cultural } \\
\text { law) }\end{array}$ \\
Pali (taboo) & $\begin{array}{l}\text { Violations of cultural values and custom- } \\
\text { ary rules can pose a risk of catastrophe for } \\
\text { individuals or communities in the respec- } \\
\text { tive village. }\end{array}$
\end{tabular}

4. Manyanggar (asking the consent of the ancestor)

Prudence in the management and utilization of natural resources.

5. Memapas Lewu (brushing the village)

6. Construction

of knowledge on local legends, stories, and experiences of the community

7. Manyalamat Petak Danum (Saving our homeland) formation in creating intersubjective collective consciousness understanding to preserve nature.

The movement to prevent damage to natural resources for the survival of future generations.

\section{Functions}

Symbols are used as a guide for all activities of human life.

Order of values and customary rules that regulate the activities of human life.

Prevention of human carelessness in managing and utilizing natural resources

Traditional ceremony to ask permission from ancestral spirits to avoid a catastrophe in managing and utilizing natural resources.

Traditional ceremonies were held every year to remind people to maintain the balance between human and human; and human with nature.

Strengthening efforts to prevent damage to sacred areas from external threats.
Activities performed by local leaders and community to convey the message that the forest destruction in Central Borneo is at an alarming level already. 


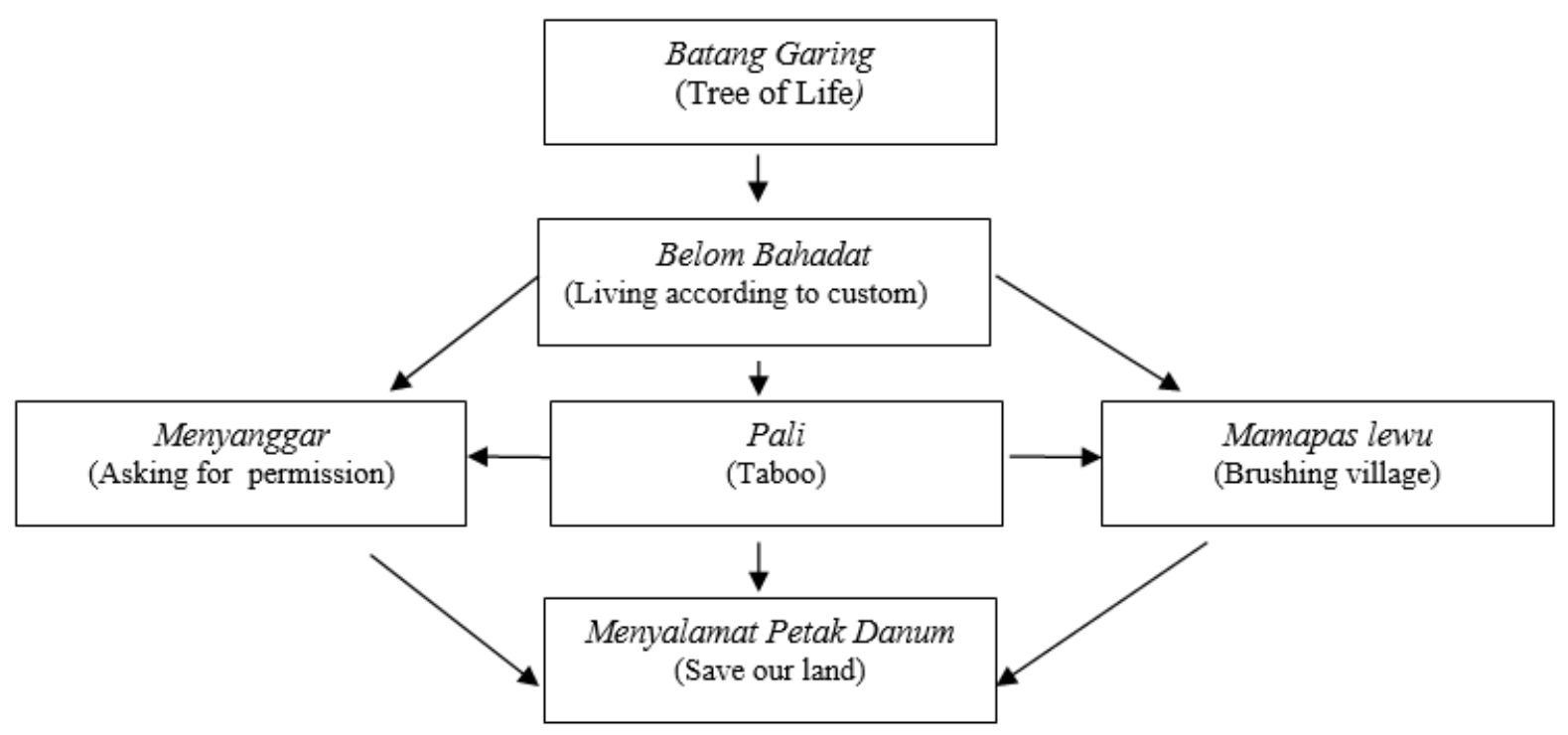

Figure 2. Indigenous Dayak Sustainability Model

Source: Usop (2016).

natural environment, and this also has taken place in Central Borneo. Thus the authors believe that the resurrection of traditional customs and knowledge can ensure a healthy balance between human and natural life in protecting the threatened land in the heart of Borneo.

\section{Conclusion}

There has been a shared awareness of the Dayak community in the pahewan region to maintain the cultural value system from outside influences which are considered to destroy the cultural value system that has been regulating people's lives in the use and management of natural resources. This understanding is a way and tool to respond to the problems identified by constructing knowledge to strengthen the local community's identity in countering information and knowledge that comes from outside the community. The process of interaction and integration drives the construction process of knowledge that shifts the meaning of pahewan from sacred forests to become conservation areas that are customarily protected. In this case, the community's role is very prominent in the protection and maintenance of conservation areas protected by indigenous peoples including sacred space, forbidden region, and community business areas. Since the conflict only causes the loss for both sides, a compromise with the community model of sustainability is advisable for investors.

\section{References}

Araújo, N., Cardoso, L., Brea, J. A. F., \& De Araújo, A. F. (2018). Green Jobs: The Present and Future of the Building Industry. Evolution Analysis. Social Sciences, 7(12), 266.

Arisanty, D., Jędrasiak, K., Rajiani, I., \& Grabara, J. (2020). The Destructive Impact of Burned Peatlands to Physical and Chemical Properties of Soil. Acta Montanistica Slovaca, 25(2), 213-223.

Arjasakusuma, S., Pribadi, U. A., \& Seta, G. A. (2018). Accuracy and Spatial Pattern Assessment of Forest Cover change Datasets in Central Kalimantan. The Indonesian Journal of Geography, 50 (2), 222-227.

Brown, G. (2015). Engaging the wisdom of crowds and public judgment for land use planning using public participation geographic information systems. Australian Planner, 52(3), 199209.

Cheung, L. T., \& Hui, D. L. (2018). Influence of residents' place attachment on heritage forest conservation awareness in a periurban area of Guangzhou, China. Urban Forestry \& Urban Greening, 33, 37-45.

Fukamachi, K. (2017). Sustainability of terraced paddy fields in traditional satoyama landscapes of Japan. Journal of Environmental Management, 202, 543-549.

Großmann, K. (2017). The (ir) relevance of ethnicity among the Punan Murung and Bakumpai in Central Kalimantan. In Continuity under Change in Dayak Societies (pp. 141-162). Springer VS, Wiesbaden.

Gupta, D., \& Koontz, T. M. (2019). Working together? Synergies in government and NGO roles for community forestry in the Indian Himalayas. World Development, 114, 326-340.

Law, E. A., Bryan, B. A., Meijaard, E., Mallawaarachchi, T., Struebig, M., \& Wilson, K. A. (2015). Ecosystem services from a degraded peatland of Central Kalimantan: implications for policy, planning, and management. Ecological Applications, 25(1), 7087.

Lestarini, R. (2016). Finding a Fair Land Dispute Settlement Mechanism Between Adat Law Community Vs. Investor. Indonesian Law Review, 6, 369.

Lounela, A. (2020) Contested values and climate change mitigation in Central Kalimantan, Indonesia. Social Anthropology, 28(4), $862-880$.

Ma'ruf, A. (2018). Agro-pastoral and preservation of local wisdom bondang for agricultural sustainability in Asahan, North Sumatra. Agricultura-Revistă de Știință și Practică Agricolă, 27 (1/2), 110-113.

Njau, A., Hakim, A., Lekson, A. S., \& Setyowati, E. (2019). Local wisdom practices of dayak indigenous people in the management of tana'ulen in the Kayan Mentarang national park of Malinau regency, North Kalimantan province, Indonesia. Russian Journal of Agricultural and Socio-Economic Sciences, 91(7), 156-167.

Osman, W. W., Shirly Wunas, D., Arifin, M., \& Wikantari, R. (2020). The Spatial Patterns of Settlement Plateau of the Ammatoa Kajang: Reflection of Local Wisdom. International Journal of Civil Engineering and Technology, 11(1), 199-208.

Pemerintah Provinsi Kalimantan Tengah (2020). Retrieved from https://www.kalteng.go.id/ on April 2, 2021

Pirard, R., Petit, H., Baral, H., \& Achdiawan, R. (2016). Perceptions of local people toward pulpwood plantations: Insights from the 
Q-method in Indonesia. International Forestry Review, 18(2), 218-230.

Rajiani, I., \& Kot, S. (2018). The Prospective Consumers of the Indonesian Green Aviation Initiative for Sustainable Development in Air Transportation. Sustainability, 10(6), 1772.

Rajiani, I., \& Pypłacz, P. (2018). National culture as modality in managing the carbon economy in Southeast Asia. Polish Journal of Management Studies, 18(1), 296-308.

Ross, A., Sherman, K. P., Snodgrass, J. G., Delcore, H. D., \& Sherman, R. (2016). Indigenous peoples and the collaborative stewardship of nature: knowledge binds and institutional conflicts. Routledge.

Savage, V. R. (2018). The Southeast Asian Haze: Dealing with an Outcome of Global Climate Cycles and Change.Pollution Across Borders: Transboundary Fire, Smoke And Haze In Southeast Asia, 205.

Silvianingsih, Y. A., Hairiah, K., Suprayogo, D., \& Van Noordwijk, M. (2020). Agroforests, swiddening and livelihoods between restored peat domes and river: effects of the 2015 fire ban in Central Kalimantan (Indonesia). International Forestry Review, 22(3), 382-396.

Sukawati, T. G. R., Riana, I. G., Rajiani, I., \& Abbas, E. W. (2020). Managing corporate sustainability by revitalizing Balinese cultural identity. Polish Journal of Management Studies, 21(1), 382-393.

Takala, T., Kähkönen, T., Laakkonen, A., \& Tikkanen, J. (2020). Towards more sustainable bioenergy production-forest owners' readiness for change.Scandinavian Journal of Forest Research, 35(1-2), 108-116.

Usop, S. R. (2016). Ruang Masyarakat Adat dalam Pemanasan Global dan Perubahan Iklim Kasus Program REDD+ di Kalimantan Tengah. Masyarakat Indonesia, 38(1), 47-68.

Walker, J. H. (2016). Beyond" Structural Contradictions": A Political Economy of Indigenous Resources Conflict in Early Nineteenth Century Northwest Borneo. Borneo Research Bulletin, 47, 84.

Wegscheider, S., Purwanto, J., Margono, B. A., Nugroho, S., Buchholz, G., \& Sugardiman, R. A. (2018). Current Achievements to Reduce Deforestation in Kalimantan. The Indonesian Journal of Geography, 50(2), 109-120.

Widen, K. (2017). The rise of Dayak identities in Central Kalimantan. In Borneo Studies in History, Society and Culture (pp. 273-282). Springer, Singapore.

Yang, H., Ranjitkar, S., Zhai, D., Zhong, M., Goldberg, S. D., Salim, M. A., \& Xu, J. (2019). Role of Traditional Ecological Knowledge and Seasonal Calendars in the Context of Climate Change: A Case Study from China. Sustainability, 11(12), 3243.

Zaki, M. K., Noda, K., Ito, K., Komariah, K., Sumani, S., \& Senge, M. (2020). Adaptation to Extreme Hydrological Events by Javanese Society through Local Knowledge. Sustainability, 12(24), 10373. 